\title{
Introduction to theory meets crisis collection
}

\author{
Liesbet Hooghe ${ }^{\mathrm{a}, \mathrm{b}}$, Brigid Laffan ${ }^{\mathrm{b}}$ and Gary Marks $\mathrm{s}^{\mathrm{a}, \mathrm{b}}$

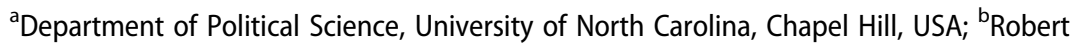 \\ Schuman Centre for Advanced Studies, European University Institute, Florence, Italy
}

This collection consists of five contributions presented as plenaries at a conference, 'Theory Meets Crisis', held at the Robert Schuman Centre, European University Institute, in July 2016. The organizers of the conference asked leading scholars of varieties of capitalism, democracy, redistributional politics, European integration and political parties to engage the theoretical implications of Europe's multiplex crisis. To what extent and how, we asked, has the European crisis confirmed, undermined or reshaped theoretically grounded expectations in these fields? Beyond the confirmation or disconfirmation of particular hypotheses, does the crisis impel us to take a fresh look at comparative politics?

Much has been written about Europe's crises in the past five years. Most of this employs extant theory to shed light on the crisis and its broader political and economic consequences. The contributions in this collection turn this perspective 180 degrees around. Each asks what one can learn from the crisis for our understanding of political institutions and behavior. How have the crises shifted problematics of research? What new puzzles and questions have come to the fore? What anomalies does the confrontation between new facts and extant theories throw up, and what novel insights emerge?

Each plenary presentation was flanked by two rapporteurs who provided extended comments: Dorothee Bohle and Torben Iversen on varieties of capitalism; Catherine de Vries and Herbert Kitschelt on democracy; Silja Häusermann and John Stephens on redistribution; Chris Bickerton and Peter Katzenstein on European integration; and Jan Rovny and Frank Schimmelfennig on political parties. While each author in this collection takes full responsibility for their published article, we would like to acknowledge that the individuals listed above are an intrinsic part of the project, and their advice was invaluable in revision.

The crisis in the title of this collection - the euro crisis and the migration crisis - raises, in sharp form, a double problematic that lies at the core of contemporary comparative politics, namely the response of national actors to international pressures, and the response of international actors to domestic 
pressures. This challenge is faced across the board in political science, but it is particularly acute in the study of Europe. In no other continent are international and domestic decision-making so densely intertwined. Each of the contributions in this collection analyzes the effects of the crisis as a multilevel process.

The contributions raise this in several guises:

- Comparative political economy. The core argument of the varieties of capitalism (VoC) approach is that complementary institutions within countries lead to disparate responses to economic interdependence. The establishment of a common currency in the eurozone puts the spotlight on this claim, and the resulting divergence in response between North and South is in line with VoC. Under the crisis, the pressure for macroeconomic adjustment in the South has become a demand for major political-economic reform. What insights can VoC offer, and how might the theory be extended to explain the current impasse in adjustment to monetary union?

- Inequality and redistribution. The literature on the politics of redistribution has focused on its domestic determinants. What is the role of macroeconomic conditions, and in particular, how does political support for redistribution respond to economic crisis? To what extent does an international economic crisis constrain domestic policy choice?

- Democracy. Economic crisis is perceived to undermine support for democracy because it weakens democratic performance. However, the experience of the crisis suggests that citizens may attest strong support for the principles of liberal democracy at the same time that they are dissatisfied with the performance of their democratic government. This suggests that we must reconsider the theoretical relationship between diffuse regime support and specific support, and it raises the possibility that the two may vary independently.

- European integration. The major theories of European integration, neofunctionalism and intergovernmentalism, were designed to explain the process by which member states achieved co-operative outcomes. Postfunctionalism counterposes the mobilization of exclusive national identity to functional pressures for co-operation. How can these theories be adapted to explain the steps taken by the European Union (EU) in response to the euro crisis and the failure of reform in response to the migration crisis?

- Political parties and party systems. Theories of democratic party competition explore how political parties take positions on issues as a strategic response to voter preferences. Yet the response of political parties to the crisis suggests that their programmatic positioning is path dependent. This provides an opening for reassessing cleavage theory, which suggests that democratic responsiveness is an emergent phenomenon that operates at the level of the party system rather than its constituent political parties. 
Party systems are responsive to the extent that the structure of party competition reflects prominent social divisions.

Peter Hall (2017) examines the tension between national variation and international collaboration in the eurozone on the varieties of capitalism premise that the comparative advantage of an economy depends on path dependent institutional complementarities. This powerfully illuminates the structural weakness of European monetary union and the difficulties of adjustment. Monetary union juxtaposed distinct growth models: a Northern exportled model based on co-ordinated markets; and a Southern domestic-led model based on mixed markets. Contrary to those who had anticipated convergence, monetary union accentuated the effect of institutional variation, producing wide current account imbalances, which fed an asset bubble in the South. The global liquidity crisis exposed and intensified structural North-South imbalances, and once the bubble burst it provoked sovereign debt crises that pushed the eurozone to the brink.

Hall contends that the crisis has challenged VoC theorists to engage more intensively with Eastern and Southern Europe and, most importantly, to problematize the effects of EU-wide policy on divergent national models and pressures for reform. Reform itself raises fundamental issues for the $\mathrm{VoC}$ research agenda relating to the role of coalitional politics among producer groups and the constraining role of postfunctionalist pressures arising from the revolt against globalization.

Jonas Pontusson and David Weisstanner (2017) argue that international macroeconomic cycles set the parameters for domestic redistributive choice. International economic developments are common forces that powerfully affect the structure of inequality and demand for redistribution. At the same time, the responsiveness of redistribution to inequality shocks varies along with political choices concerning the generosity and inclusiveness of social insurance benefits. The Great Recession in Europe offers the most recent illustration. Using Luxembourg Income Study and EU-SILC data, Pontusson and Weisstanner show that governments in North-west Europe have turned less to compensatory redistribution than in the economic downturn of the early 1990s. This reflects the structure of inequality that concentrates unemployment and poverty risk among low-educated immigrants and minorities, and which, correspondingly, leads middle-income citizens to be more willing to cut redistribution to the poor. The logic extends to Southern Europe, but because the euro crisis there deepened insecurity and inequality across broad sections of society, the political outcome was diametrically different: public support for redistribution rose sharply, and so did redistributive policy, at least until the eurozone imposed austerity.

Hanspeter Kriesi (2017) finds that the Great Recession confirms the theory of the 'critical citizen'. This theory claims that citizens meaningfully distinguish 
between support for democratic principles and evaluation of democratic practice. While bad economic times make citizens more critical of democratic practice, they also reduce tolerance for poor governance and can bolster support for democratic principles. The theory takes issue with David Easton's view that diffuse systemic support is, in the long run, the product of evaluations of outputs and performance. Using fine-grained survey data from a 2012 European Social Survey, Kriesi finds a pronounced divergence in democratic satisfaction across Europe alongside robust principled support for democracy. In North-west Europe, satisfaction and support continue to go hand in hand; in Southern Europe satisfaction drops precipitously while principled support is stable; and in Central and Eastern Europe, the crisis has reinforced a longstanding gap between satisfaction and support. Interestingly, the most adversely affected citizens have the most maximalist conceptions of democracy. By creating critical citizens, the economic crisis actually contributes to the strengthening of democratic principles.

Tanja Börzel and Thomas Risse (2017) probe how theories of European integration fare in explaining the partially successful response of the EU to the euro crisis and the subsequent blockage in dealing with the Schengen crisis. They observe that the initial response to the euro crisis used intergovernmentalist means to achieve neofunctionalist ends: government leaders sought to contain politicization by delegating fiscal powers to non-majoritarian supranational institutions. The upshot was a marked centralization of fiscal and economic authority which produced a postfunctionalist backlash that compressed the winset for intergovernmental bargaining on the migration crisis. In the face of an insiders versus outsiders narrative that amplifies exclusive nationalism, EU decision-making failed and government after government retreated into unilateral national decision-making.

Börzel and Risse argue that each of these theories has something to offer, but no one of them provides a sufficient explanation across the board. Together, liberal intergovernmentalism and neofunctionalism can account for the response to the euro crisis. Postfunctionalism offers a good account of the failure to respond to refugee flows with a co-ordinated response, and its emphasis on constraining dissensus is a necessary ingredient in explaining Europe's problem-solving challenge overall. However, postfunctionalism tends to underestimate the resilience of the EU: the relative insulation of EU non-majoritarian institutions from politicization; the capacity of élites to circumvent the constraining dissensus and to learn from mistakes; and, most importantly, the double-edged character of identity and its receptiveness to framing. A theory of European integration, according to Börzel and Risse, needs to take up under what conditions, how, and to what effect, these identities can be framed in support of transnational governance.

Liesbet Hooghe and Gary Marks (2017) suggest that we need to reassess some basic priors about political parties and party systems in the light of 
Europe's crises. The Downsian assumption that political parties reposition themselves in response to changing voters' preferences is challenged by the decline in the vote share of mainstream parties across Europe and the rise of green and radical right parties. These parties are rooted in a new divide - which Hooghe and Marks describe as a transnational cleavage - activated by a nationalist reaction against the European Union and immigration. Cleavage theory assumes that political parties arise in response to critical junctures and that they are programmatically rooted. Party systems respond to major exogenous change by producing new parties that compete on new divides. Europe's crises are critical junctures that introduce new divisions into party systems.

However, Lipset and Rokkan's (1967) original theory cannot be transplanted wholesale. Its core contribution is to offer a coherent explanation for the inelasticity of party positioning, the relatively high incidence of divisions within mainstream parties on Europe and immigration, and, more generally, the failure of mainstream parties to encompass voters mobilized on transnational issues. The claim that party systems are frozen, which Lipset and Rokkan themselves soon dropped, is self-evidently extraneous. More importantly, the notion that citizens are locked in bounded, organized, and self-conscious groups no longer holds. However, the question of persistence remains on the table. How durable are the issues that underpin the new cleavage? How durable are attachments of voters to challenging political parties? Has a period of de-alignment been superseded by a new structuration of parties and attachments?

Although the focus of these contributions was on the European Union and its attendant crises, the scholarly insights of the collection are of value beyond the study of Europe, because the EU is a laboratory for the management or failure to manage interdependence. As the world is becoming ever more complex and the functional pressures for collective solutions more pressing, these contributions underline the importance of domestic political anchorage for transnational politics and policy.

\section{Disclosure statement}

No potential conflict of interest was reported by the authors.

\section{Notes on contributors}

Liesbet Hooghe is W.R. Kenan Distinguished Professor of Political Science at the University of North Carolina, Chapel Hill, and Robert Schuman Fellow, European University Institute, Florence.

Brigid Laffan is the professor and director at the Robert Schuman Centre for Advanced Studies, European University Institute, Florence. 
Gary Marks is Burton Craige Distinguished Professor of Political Science at the University of North Carolina, Chapel Hill, and Robert Schuman Fellow, European University Institute, Florence.

\section{References}

Börzel, T. and Risse, T. (2017) 'From the euro to the Schengen crisis: European integration theories, politicization, and identity politics', Journal of European Public Policy. doi:10.1080/13501763.2017.1310281

Hall, P. (2017) 'Varieties of capitalism in light of the euro crisis', Journal of European Public Policy. doi:10.1080/13501763.2017.1310278

Hooghe, L. and Marks, G. (2017) 'Cleavage theory meets Europe's crises: Lipset, Rokkan, and the transnational cleavage', Journal of European Public Policy. doi:10.1080/ 13501763.2017.1310279

Kriesi, H. (2017) 'The implications of the euro-crisis for democracy', Journal of European Public Policy. doi:10.1080/13501763.2017.1310277

Lipset, S.M. and Rokkan, S. (1967) 'Cleavage structures, party systems, and voter alignments: an introduction', in S.M. Lipset and S. Rokkan (eds), Party Systems and Voter Alignments: Cross-National Perspectives, Toronto: The Free Press, pp. 1-64.

Pontusson, J. and Weisstanner, D. (2017) 'Macroeconomic conditions, inequality shocks and the politics of redistribution, 1990-2013', Journal of European Public Policy. doi:10.1080/13501763.2017.1310280 